\title{
WKEAD KATEDR PATROLOGII KUL W PRZYBLIŻANIE NAUKI OJCÓW KOŚCIOŁA
}

Niniejsza relacja jest rekonstrukcją historii Katedry Patrologii w Katolickim Uniwersytecie Lubelskim. Owej rekonstrukcji dokonano w oparciu o artykuły dotyczące Seminarium Patrystycznego, które niedawno ukazały się w pracach zbiorowych ${ }^{1}$ oraz dość skąpe i lakoniczne informacje zamieszczone w opracowaniach dotyczących bądź historii teologii katolickiej w Polsce ${ }^{2}$, bądź życia i działalności osób odpowiedzialnych za Katedrę Patrologii ${ }^{3}$.

\section{RYS HISTORYCZNY}

Od samego początku istnienia Katolickiego Uniwersytetu Lubelskiego studenci mieli możliwość zgłębiania myśli Ojców Kościoła i starożytnych pisarzy kościelnych. Patrologia jako przedmiot pojawiła się bowiem po raz pierwszy w planie zajęć Wydziału Teologicznego KUL już na rok akademicki 1919/1920 (semestr letni). Obok nazwy przedmiotu zamieszczono informację, że nazwisko wykładowcy zostanie podane później ${ }^{4}$. Podobna notatka została zamieszczona w spisie wykładów na rok akademicki 1921/1922; dopiero w planie zajęć na rok 1922/1923 figuruje nazwisko ks. Jana Czuja jako wykładowcy patrologii, zastępcy profesora (semestr letni). W roku następnym

${ }^{1}$ Por. F. Drączkowski, Katedra Patrologii w Katolickim Uniwersytecie Lubelskim (rys historyczny), w: Tysiąc imion Chrystusa. Seminarium Patrystyczne KUL 1983-1993, red. F. Drączkowski - J. Pałucki, Lublin 1994, 9-15; J. Pałucki, Katedra Patrologii w Katolickim Uniwersytecie Lubelskim, w: Sympozja Kazimierskie poświęcone kulturze świata późnego antyku i wczesnego chrześcijaństwa, red. B. Iwaszkiewicz-Wronikowska, Lublin 1998, 145-150.

${ }^{2}$ Chodzi tu głównie o artykuły: J. M. Szymusiak, Zarys dziejów patrystyki, w: Dzieje teologii katolickiej w Polsce, t. III, cz. 1, pod red. M. Rechowicza, Lublin 1976, 67-103, oraz: A. Bober, Wkład nauki polskiej do badań nad antykiem chrześcijańskim, STV 9(1971) nr 1, 21-50.

3 Najważniejsze są tu dwa artykuły S. Longosza: O. Andrzej Bober SJ, VoxP 4(1984) z. 6-7, 9-17; Jan Maria Szymusiak SJ 1920-1987. Calendarium vitae, VoxP 9(1989) z. 16, 9-16.

${ }^{4}$ Por. Spis wykładów i wykaz instytucji uniwersyteckich, Lublin 1920. 
pojawia się informacja o prowadzonym przez niego seminarium patrystycznym. Wszystko zdaje się wskazywać na to, że rok 1923 należy uznać za datę inicjującą działalność Katedry Patrologii w Katolickim Uniwersytecie Lubelskim. Jej pierwszy kierownik, ks. Jan Czuj, urodził się 20 maja 1886 roku w Borzęcinie (koło Brzeska) ${ }^{5}$. Święcenia kapłańskie przyjął w 1912 roku, po studiach w Wyższym Seminarium Duchownym w Tarnowie. Doktorat z teologii uzyskał w 1916 roku na Uniwersytecie Jagiellońskim. W latach 1920-1922 „,specjalizował się na Gregorianum, gdzie otrzymał równoznaczny z habilitacją tytuł magister aggregatus; po powrocie do kraju wykładał patrologię i homiletykę w KUL (1923-1929), a następnie w Uniwersytecie Warszawskim, gdzie w 1938 roku został profesorem"6. W czasie sześcioletniej pracy w KUL sporo uwagi poświęcił badaniom doktryny św. Augustyna i św. Cypriana. Owocem tych zainteresowań są prace publikowane przez niego w tym okresie ${ }^{7}$. Można przypuszczać, że miało to wpływ na profil naukowy seminarium patrystycznego, którym kierował. W świetle obecnego stanu badań trudno jednak coś bliżej powiedzieć na ten temat. Ks. Jan Czuj zmarł 2 sierpnia 1957 roku w Warszawie.

Ciąg dalszy historii Katedry Patrologii jest dość niezwykły i z wielu przyczyn bardzo trudny do przedstawienia. Pierwsza trudność wynika z podstawowego faktu, że po odejściu ks. J. Czuja, tj. od 1929 roku przez następne 55 lat, tj. do 1984 roku, Katedra Patrologii nie była formalnie obsadzona ${ }^{8}$. Wynikało to $\mathrm{z}$ dość rygorystycznych przepisów, w myśl których kierownikiem Katedry mógł być mianowany tylko doktor habilitowany, zatrudniony na stanowisku docenta. Dalsza trudność wynika z braku materiałów źródłowych. Chodzi głównie o księgi protokołów z posiedzeń seminarium patrystycznego.

W historii Katedry Patrologii, od 1929 roku do chwili obecnej, można wyróżnić pięć okresów:

- okres pierwszy, obejmujący lata od 1929 do 1958;

- okres drugi, od 1958 do 1971 roku;

- okres trzeci, od 1971 do 1982 roku;

- okres czwarty, od 1982 do 1997 roku;

- okres piąty, po 1997 roku.

5 Por. W. Kania, Ks. Jan Czuj wybitny krzewiciel myśli patrystycznej w Polsce, TST 8(1981) 357-364; EK III 926.

6 Tamże.

7 Por. Kościót Katolicki u św. Augustyna, PT 4(1923) z. 3, 209-227; z. 4, 281-298; Jak się dokonało nawrócenie św. Augustyna, „Miesięcznik Katechetyczny i Wychowawczy” 14(1925) 333-339; Hierarchia kościelna u św. Augustyna, Lublin 1925; Św. Cyprian biskup męczennik, Kraków 1927; Św. Augustyn o Żydach, Kraków 1928.

${ }^{8}$ Por. J.M. Szymusiak, Zarys dziejów patrystyki, dz. cyt., 99: „Katedra Patrologii, od chwili ustąpienia ks. J. Czuja (1929), nie była obsadzona" (przypis 109). W roku 1984 kierownikiem Katedry Patrologii został mianowany ks. F. Drączkowski. 
1. Okres od 1929 do 1958 roku. W tym okresie brak jest wzmianek w opracowaniach naukowych na temat działalności Katedry Patrologii. Wszystko zdaje się wskazywać na to, że były to lata zastoju. Czas zawieruchy wojennej oraz trudne lata powojenne nie stanowiły okoliczności sprzyjających rozwojowi nauk teologicznych. Okres ten czeka nadal na swoje opracowanie. Trudno przypuszczać, by zasoby archiwalne KUL zawierały jakieś pełniejsze materiały odnośnie do tego okresu historii Katedry Patrologii.

2. Okres od 1958 do 1971 roku. Powyższy zastój został przełamany z chwilą przejęcia wykładów z patrologii w KUL przez o. Jana Marię Szymusiaka. Z jego osobą wiązano wielkie nadzieje, które $-\mathrm{z}$ bardzo wielu złożonych przyczyn spełniły się tylko częściowo.

O. Jan Maria Szymusiak urodził się 27 listopada 1920 roku w Prötzel $\left(\right.$ RFN) ${ }^{9}$. Studiował we Francji (Lyon, Paryż, Vals-Le Puy), w Belgii (Enghien) oraz we Włoszech (Rzym). W roku 1957 uzyskal doktorat z teologii dogmatycznej na podstawie pracy Eléments de la théologie de l'homme chez S. Grégoire de Nazianze. W latach 1957-1958 wykładał patrologię w Uniwersytecie Gregoriańskim w Rzymie. W roku 1958 uzyskał doktorat z nauk humanistycznych na Sorbonie w Paryżu, na podstawie rozprawy: L'homme et sa destinée selon Grégoire le Theologien, napisanej pod kierunkiem prof. H.I. Marrou. Jesienią tegoż roku podjął wykłady zlecone $\mathrm{z}$ patrologii w KUL-u oraz na jezuickim Wydziale Teologicznym „Bobolanum” w Warszawie. W roku 1966 uzyskał stopień doktora habilitowanego na Wydziale Teologicznym KUL na podstawie pracy: Grzegorz Teolog. U źródet myśli chrześcijańskiej IV wieku, (Poznań 1965). W rok później został powołany na p.o. kierownika Katedry Patrologii KUL. W roku 1971 Senat Akademicki KUL powołał go na stanowisko docenta, niestety Ministerstwo Oświaty i Szkolnictwa Wyższego nie zatwierdziło tej decyzji. W roku 1971 o. Szymusiak opuścił Polskę i nigdy już do niej nie wrócił. Zmarł w Paryżu dnia 11 września 1987 roku.

W swych badaniach koncentrował się na twórczości Atanazego Wielkiego i Grzegorza z Nazjanzu. Zajmował się również Ariuszem i jego nauką. W roku 1956 opublikował w serii Sources Chrétiennes krytyczną edycję dwóch apologii Atanazego (SCh 56) ${ }^{10}$, zaś w 1987 roku postarał się o ich drugie wydanie (SCh 56 bis).

O. Jan Maria Szymusiak prowadził seminarium patrystyczne przez cztery lata (1967-1971). W cotygodniowych posiedzeniach uczestniczyło od 10 do

${ }^{9}$ Por. Ks. S. Longosz, Jan Maria Szymusiak SJ (1920-1987). Calendarium vitae, VoxP 9(1989) z. $16,9-16$.

${ }^{10}$ Por. S. Athanase, Apologie à l'empereur Constance. Apologie pour sa fuite. Introduction, texte critique, traduction et notes, Paris 1958, ss. 192. 
15 osób, zarówno z kursu wyższego „A”, jak i z kursu „B”. Katedra Patrologii od 1964 roku strukturalnie przynależy do Instytutu Historii Kościoła (Wydział Teologii). $\mathrm{Z}$ tej racji w posiedzeniach tego seminarium uczestniczyli przede wszystkim studenci historii Kościoła. Nie brakowało też młodych entuzjastów $\mathrm{z}$ innych sekcji, a nawet wydziałów. Wszystkich przyciągała jak magnes niezwykła osobowość prowadzącego seminarium. Ojciec Docent, bo tak go nazywano, imponował wszechstronną wiedzą z zakresu historii i literatury starożytnej oraz doskonałą znajomością języków klasycznych i nowożytnych, głównie języka francuskiego. Wobec seminarzystów był zawsze wyrozumiały, ojcowski, życzliwy i tolerancyjny. Swoje opinie, często bardzo krytyczne - tak wobec władz państwowych jak i kościelnych - wyrażał otwarcie, czym ogromnie imponował swoim uczniom. Być może było to jednym z czynników, które zadecydowały o jego „wydaleniu” z Polski. Należy dodać, że o. Szymusiak wyjechał z Polski wbrew swojej woli, na wyraźne żądanie władz państwowych i z nakazu władz zakonnych ${ }^{11}$. Pod kierunkiem o. Jana Marii Szymusiaka powstały na KUL-u dwie prace licencjackie w ramach seminarium patrystycznego - ks. Franciszka Drączkowskiego, Zagadnienie postu według św. Leona Wielkiego (1970) oraz ks. Stanisława Longosza, Problem literackiej spuścizny Ariusza (1971).

Wkład o. Szymusiaka w rozwój polskiej patrologii należy uznać za bardzo ważny. Jego odejście było niepowetowaną stratą. Wyrazem uznania i hołdu dla jego zasług jest dedykowany mu pośmiertnie 16 tom „Vox Patrum” (1987, ss. 556) przedstawiający oprócz przyczynków naukowych wyczerpująco jego życiorys oraz działalność naukową i dydaktyczną.

3. Okres od 1971 do 1982 roku. Katedra Patrologii, po odejściu o. Jana Marii Szymusiaka, przez następne 12 lat nie posiadała pracownika samodzielnego. $\mathrm{Z}$ tej racji w dalszym ciągu nie była obsadzona, co więcej - nie posiadała nawet kogoś, kto by pełnił obowiązki kierownika Katedry, jak to było w okresie poprzednim. Władze uczelniane, poszukując osoby najbardziej nadającej się na to stanowisko, zaprosiły do współpracy człowieka, który wówczas cieszył się opinią jednego z najznakomitszych patrologów polskich, o. dra Andrzeja Bobera SJ, znanego z popularnej Antologii Patrystycznej ${ }^{12}$.

O. Andrzej Bober SJ urodził się 1 stycznia 1917 roku w Starej Wsi (woj. krośnieńskie) $)^{13}$. W 1943 roku przyjął święcenia kapłańskie. Od 1945 roku studiował w Uniwersytecie Jagiellońskim w Krakowie. W roku 1950 uzyskał

${ }^{11} \mathrm{Na}$ podstawie rozmowy, którą F. Drączkowski przeprowadził z o. Szymusiakiem w lipcu 1974 roku podczas pobytu w Paryżu.

12 Por. Światta Ekumeny. Antologia Patrystyczna, Kraków 1965, ss. 648.

13 Por. Ks. S. Longosz, O. Andrzej Bober SJ, VoxP 4(1984) z. 6-7, 9-17; tenże, Ojciec Bober jako filolog i patrolog (1917-1986), VoxP 6(1986) z. 10, 195-410; L. Grzebień, Bober Andrzej (1917-1986), SPTK VIII 95-100. 
stopień magistra filologii klasycznej; w 1954 roku stopień doktora teologii na podstawie pracy pt. Święty Augustyn w Polsce. Wykładał patrologię oraz języki klasyczne na jezuickim Wydziale Teologicznym w Krakowie i w Warszawie, w Śląskim Wyższym Seminarium Duchownym oraz w Częstochowskim Wyższym Seminarium Duchownym w Krakowie. W latach 1971-1983 wykładał patrologię oraz prowadził proseminarium w Katolickim Uniwersytecie Lubelskim. Zajmował się szczególnie patrystyką iroszkocką i anglosaską oraz historią polskiej patrystyki. Jest autorem 204 prac naukowych i popularnonaukowych $^{14}$. O. Andrzej Bober był lubiany i ceniony jako wykładowca patrologii dzięki swej imponującej erudycji, niezwykłej „swadzie” oraz pasji, z jaką prezentował wykładany materiał. Nie stronił od niezwykłych, mało znanych i dziwnych szczegółów. Lubował się w przedstawianiu wydarzeń osobliwych, czym wywoływał wiele radości u braci studenckiej, przez którą wspominany jest z sympatią i wdzięcznością. Od swych uczniów wymagał bardzo dobrej znajomości łaciny i greki. $\mathrm{Z}$ tej racji prowadzone przez niego proseminarium nie cieszyło się zbyt dużą frekwencją. Opiekował się i kierował pracami pisanymi w różnych ośrodkach naukowych. Był promotorem 8 prac magisterskich powstałych na seminarium patrystycznym prowadzonym przez ks. dra Bogdana Częsza w Gorzowie Wielkopolskim. Był także promotorem pracy magisterskiej powstałej na seminarium ks. dra Romana Andrzejewskiego: Jerzy Pałucki, Recepcja nauki św. Augustyna na tamach „Ateneum Kapłańskiego” w latach 1909-1980 (Włocławek 1981).

W roku 1982 o. dr Andrzej Bober przeszedł na emeryturę, jednak jeszcze w roku akademickim 1982-1983 wykładał patrologię w KUL na kursie „B”. Gromadził materiały do dwóch prac, a mianowicie: rozprawy habilitacyjnej oraz nowej, obszernej (obliczonej na 5 tomów) antologii patrystycznej pt. Millennium $^{15}$. Niestety obu tych przedsięwzięć nie udało mu się zrealizować, Bóg przedwcześnie powołał go do wieczności. Zmarł 15 marca 1986 roku w Krakowie. Wyrazem uznania wielkich zasług o. Andrzeja Bobera dla polskiej patrologii jest 6-7 tom „Vox Patrum” (ss. 512) dedykowany mu przez kolegów, przyjaciół i uczniów z okazji jubileuszu 35-lecia pracy dydaktycznej ${ }^{16}$.

4. Okres od 1982 do 1997 roku. Od roku 1982 losy Katedry Patrologii KUL związane są z osobą ks. prof. Franciszka Drączkowskiego. Urodził się on 26 kwietnia 1941 roku w Fordonie. Podczas studiów w Wyższym Seminarium

${ }^{14}$ Por. S. Longosz, Wykaz drukowanych prac o. Andrzeja Bobera, VoxP 4(1984) z. 6-7, 21-39; L. Grzebień, j.w., s. 96-100.

${ }^{15}$ Por. A. Bober, Millennium. Pierwsze tysiąclecie chrześcijaństwa w świetle tekstów źródtowych, VoxP 1(1981) z. 1, 103-105. Po jego śmierci ukazal się tom V tej antologii: Millennium, t. 5: Anglia - Szkocja - Irlandia. Teksty źródłowe do historii Kościoła i patrystyki I-IX w., Lublin 1991, ss. 136.

16 Por. Wręczenie Księgi Pamiq̨tkowej Ojcu A. Boberowi, VoxP 5(1985) z. 8-9, 509-510. 
Duchownym w Pelplinie nawiązał korespondencję z o. dr. Janem Marią Szymusiakiem, wykładowcą patrologii w KUL. Za jego radą podjął badania nad myślą Leona Wielkiego. W 1966 roku przyjął święcenia kapłańskie. W roku 1968 został skierowany na studia specjalistyczne z patrologii w Instytucie Historii Kościoła KUL w Lublinie. Po roku podjął równolegle regularne studia z filologii klasycznej na Wydziale Nauk Humanistycznych KUL. W czerwcu 1970 roku uzyskał licencjat i stopień magistra teologii z zakresu historii Kościoła na podstawie pracy: Zagadnienie postu według Leona Wielkiego, napisanej pod kierunkiem o. dra hab. J. M. Szymusiaka. We wrześniu 1973 roku uzyskał stopień magistra filologii klasycznej na podstawie pracy: Struktury semantyczne wyrazu paideia w ,Stromateis” Klemensa Aleksandryjskiego, napisanej pod kierunkiem prof. J. Pliszczyńskiej. W listopadzie tegoż roku obronił pracę doktorską z patrologii pt. Formy i zasady pierwszych wspólnot chrześcijańskich na podstawie „Stromatów” Klemensa Aleksandryjskiego, której promotorem był ks. prof. B. Kumor. Bezpośrednio po tym został skierowany na dalsze studia do Rzymu, gdzie w latach od 1973 do 1976 studiował w Institutum Altioris Latinitatis w Universita Salesiana. W czerwcu 1975 roku uzyskał licencjat ex litteris classicis et christianis na podstawie pracy pt. De nonnullis praecipuis proclivitatibus antiquarum sectarum heterodoxarum secundum Clementis Alexandrini, napisanej pod kierunkiem prof. Calogero Riggi. We wrześniu 1976 roku uzyskał stopień doktora ex litteris classicis et christianis na podstawie rozprawy pt. Qua paideia Clemens Alexandrinus imbutus appareat in animadvertenda falsa gnosi, napisanej również pod kierunkiem prof. Calogero Riggi. Dnia 1 października 1976 roku podjął pracę w Międzywydziałowym Zakładzie Leksykograficznym KUL, najpierw jako dokumentalista, a od 1978 roku na stanowisku adiunkta. W roku 1980 został mianowany redaktorem działu teologii patrystycznej i patrologii Encyklopedii Katolickiej. Oprócz pisania i redagowania haseł do Encyklopedii Katolickiej z patrologii, filologii klasycznej i religioznawstwa, kontynuował badania nad myślą Klemensa Aleksandryjskiego. Owocem tych wysiłków była rozprawa habilitacyjna pt. Kościót - Agape wedtug Klemensa Aleksandryjskiego, napisana w maju 1980 roku. Kolokwium habilitacyjne odbyło się 9 grudnia 1981 roku na Wydziale Teologicznym KUL. W roku 1982 zaczął wykładać patrologię (wykład kursoryczny) w Wyższym Seminarium Duchownym w Lublinie oraz sakramentologię patrystyczną w Wyższym Seminarium Duchownym w Pelplinie. W tym samym roku Rada Wydziału Teologicznego KUL powierzyła mu prowadzenie proseminarium naukowego z patrologii. W 1983 roku został powołany na stanowisko p.o. kierownika Katedry Patrologii. Powierzono mu wykłady kursoryczne z patrologii na Wydziale Teologicznym (kurs „B”) oraz prowadzenie seminarium naukowego. W 1984 roku został zatrudniony na stanowisku docenta w KUL oraz otrzymał nominację na kierownika Katedry Patrologii. Należy nadmienić, że Katedra Patrologii w KUL, „od chwili ustąpienia ks. J. Czuja (1929), nie była 
obsadzona"17. W ten sposób Katedra Patrologii KUL, po 55 latach przerwy, znów otrzymała swego kierownika (o. dr hab. J. M. Szymusiak został powołany tylko na p.o. kierownika Katedry Patrologii we wrześniu 1967 roku i funkcję tę pełnił do 1971 roku). Dnia 27 stycznia 1992 roku został zatrudniony na stanowisku profesora nadzwyczajnego KUL; w marcu tegoż roku otrzymał tytuł naukowy profesora nauk teologicznych. W latach 1994-1997 był pierwszym rektorem Wyższego Seminarium Duchownego w Toruniu.

Ks. Franciszek Drączkowski pełnił (lub pełni nadal) następujące funkcje:

- Członka Rady Naukowej „Vox Patrum” - od 1981 roku;

- Członka Komisji Rewizyjnej Towarzystwa Przyjaciół KUL - od 19851991 roku;

- Przewodniczącego Wydziału Teologiczno-Kanonicznego TN KUL - od 1987-1990 roku;

- Kuratora Koła Filologicznego - od 1987 roku;

- Prodziekana Wydziału Teologicznego - od 1990-1993 roku;

- Przewodniczącego Sekcji Patrystycznej przy Komisji Episkopatu d/s. Nauki Katolickiej - od 1990-1996 roku.

Ks. F. Drączkowski jest autorem 158 prac drukowanych, w tym 9 pozycji książkowych i 91 artykułów w Encyklopedii Katolickiej. Jest on także promotorem 137 prac magisterskich i 9 rozpraw doktorskich ${ }^{18}$.

Ważnym wydarzeniem w historii Katedry Patrologii KUL było zatrudnienie przy niej asystenta. Został nim w 1991 roku ks. dr Jerzy Pałucki (adiunkt od 1993 r.). W roku zaś 1996 asystentem w Katedrze Patrologii został ks. dr Mariusz Szram. Urodził się on 16 lutego 1965 roku w Olsztynie. Po ukończeniu studiów w Warmińskim Seminarium Duchownym „Hosianum” w Olsztynie przyjął święcenia kapłańskie w 1989 roku. W latach 1990-1996 odbył studia magisterskie z filologii klasycznej na Wydziale Nauk Humanistycznych KUL i doktoranckie $\mathrm{z}$ historii Kościoła i patrologii w Instytucie Historii Kościoła na Wydziale Teologii KUL. Doktoryzował się w 1996 roku na podstawie pracy pt. Chrystus - Mądrość Boża wedtug Orygenesa, napisanej pod kierunkiem ks. prof. dr. hab. Franciszka Drączkowskiego. Od 1995 roku prowadził zajęcia zlecone, a od 1996 roku został zatrudniony jako asystent przy Katedrze Pa-

${ }^{17}$ Por. J.M. Szymusiak, Zarys dziejów patrystyki, dz. cyt. s. 99.

18 Por. Józef Grzywaczewski, Modlitwa w duchu Agape wedtug Klemensa Aleksandryjskiego, (1987); Jerzy Pałucki, Chrystus Boski Lekarz, Wychowawca i Nauczyciel w pismach Klemensa Aleksandryjskiego, (1987); Aleksy Kowalski, Obraz człowieka w „Stromatach” Klemensa Aleksandryjskiego, (1991); Piotr Paciorek, Pismo św. jako reguta wiary i moralności Kościoła na podstawie „Enarrationes in Psalmos” św. Augustyna, (1991); Leopold Rzodkiewicz, Chrystus przepowiadany Hellenom w pismach Klemensa Aleksandryjskiego, (1991); Norbert Widok, Akomodacja misyjna $w$ teorii i praktyce Klemensa Aleksandryjskiego, (1991); Dariusz Drążek, Pojęcie „disciplina” w pismach św. Cypriana, (1994); Mariusz Szram, Chrystus - Mądrość Boża w nauce Orygenesa, (1996); Wojciech Piątek, Sprawiedliwy rozraduje się w Panu w świetle „Enarrationes in Psalmos" św. Augustyna, (1998). 
trologii Greckiej na Wydziale Teologii KUL. Jest członkiem Polskiego Towarzystwa Filologicznego, Sekcji Patrystycznej przy Komisji Episkopatu do Spraw Nauki Katolickiej, Komisji Badań nad Antykiem Chrześcijańskim oraz Komisji Bizantynologicznej PAN. Jest autorem 2 książek i kilkunastu artykułów naukowych. Głównym przedmiotem jego zainteresowań jest teologia i egzegeza szkoły aleksandryjskiej (III-V w.). Obecnie przygotowuje rozprawę habilitacyjną na temat duchowego sensu liczb w aleksandryjskiej egzegezie alegorycznej.

5. Okres po 1997 roku. Dnia 15 II 1997 r. decyzją Rektora KUL na wniosek Rady Wydziału Teologii rozwiązano Katedrę Patrologii, a na jej miejsce utworzono Katedrę Patrologii Greckiej (kierownikiem został ks. prof. dr hab. Franciszek Drączkowski) i Katedrę Patrologii Łacińskiej, której kierownikiem został ks. dr hab. Jerzy Pałucki.

Ks. Jerzy Pałucki urodził się 26 marca 1955 roku w Goszczanowie koło Kalisza. Święcenia kapłańskie przyjął w 1981 roku, po studiach w Wyższym Seminarium we Włocławku. W latach 1984-1988 studiował patrologię w Instytucie Historii Kościoła w KUL, uzyskując stopień doktora na podstawie pracy pt. Chrystus Boski Lekarz, Wychowawca i Nauczyciel w pismach Klemensa Aleksandryjskiego. Następnie został skierowany na trzyletnie studia specjalistyczne do Rzymu, w Institutum Altioris Latinitatis, przy Papieskim Uniwersytecie Salezjańskim. W 1990 roku uzyskał licencjat ex litteris classicis et christianis i został zatrudniony w Międzywydziałowym Zakładzie Leksykograficznym KUL w Lublinie. W rok później otrzymał stanowisko asystenta w Katedrze Patrologii. W roku 1993 został zatrudniony na stanowisku adiunkta w Katedrze Patrologii. Owocem prowadzonych prze niego badań własnych była rozprawa habilitacyjna pt. Święty Ambroży jako duszpasterz w świetle ekshortacji pastoralnych (Lublin 1996). Dnia 16 maja 1996 roku odbyło się jego kolokwium habilitacyjne, a 6 III 1999 roku otrzymał stanowisko profesora nadzwyczajnego KUL.

Ks. Jerzy Pałucki pełnił lub pełni następujące funkcje:

- Sekretarza Sekcji Patrystycznej przy Komisji Episkopatu ds. Nauki Katolickiej - od 1994-1996 roku;

- Przewodniczącego Sekcji Patrystycznej przy Komisji Episkopatu ds. Nauki Katolickiej - od 1996 roku;

- Członka Naczelnej Redakcji Encyklopedii Katolickiej - od 1 X 1997 roku;

- Prodziekana Wydziału Teologii KUL - od 25 IV 1998 roku;

- Przewodniczącego Senackiej Komisji Kontrolnej oraz Członka Senackiej Komisji Młodzieżowej - od 30 VII 1998 roku.

Ks. prof. dr hab. Jerzy Pałucki jest autorem 65 prac drukowanych, w tym 4 pozycji książkowych i 5 artykułów w języku włoskim oraz redaktorem 
i współredaktorem 5 książek. Jest również promotorem 11 prac magisterskich, które powstały na seminarium przy Katedrze Patrologii Łacińskiej ${ }^{19}$. Razem z kierownikiem Międzywydziałowego Zakładu Badań nad Antykiem Chrześcijańskim był organizatorem międzynarodowego Kongresu Ambrozjańskiego w KUL, który odbył się w dniach 25 - 26 XI 1997 roku.

\section{KIERUNKI BADAŃ PRACOWNIKÓW KATEDRY}

Wśród badań prowadzonych przez pracowników Katedry można wyróżnić kilka zasadniczych grup tematycznych. Ks. Jan Czuj, w czasie pracy w KUL, koncentrował się na badaniu doktryny św. Augustyna i św. Cypriana. Ks. Jan Szymusiak zajmował się badaniem myśli św. Atanazego Wielkiego, Ariusza i św. Grzegorza z Nazjanzu - szczególnie jego antropologią. O. Andrzej Bober interesował się w sposób szczególny patrystyką iroszkocką i anglosaską oraz historią polskiej patrystyki. Ks. prof. F. Drączkowski zajmuje się agapetologią, eklezjologią oraz szeroko rozumianą paideią. Przygotował podręcznik patrologii dla studentów ${ }^{20}$ oraz popularyzuje naukę Ojców Kościoła m.in. w audycjach radiowych $^{21}$. Ks. prof. J. Pałucki prowadzi badania nad społeczną nauką Kościoła w starożytności o ukierunkowaniu pastoralnym. Recenzenci jego dorobku naukowego podkreślają, że artykuły na pozór nawet bardzo teoretyczne, jak np. Osoba - rozwój terminologii czy Epitafium z Cymitile, będące filologicznymi dywagacjami, ostatecznie ukazują bardzo praktyczne wnioski. Ks. dr M. Szram, pozostając zasadniczo na gruncie patrologii greckiej, zajmuje się szczególnie chrystologią i egzegezą alegoryczną. Jego badania przybliżają polskiemu środowisku mało znaną w Polsce, niezwykle trudną i kontrowersyjną, ale równocześnie podstawową dla teologa naukę Orygenesa.

Pracownicy Katedry (jako kolejni prezesi Sekcji Patrystycznej przy Komisji Episkopatu Polski ds. Nauki Katolickiej) są organizatorami dorocznych sympozjów patrystycznych, z których materiały ukazują się drukiem pod ich redakcją ${ }^{22}$.

${ }^{19}$ Wykaz prac dyplomowych (magisterskich, doktorskich i habilitacyjnych) z patrologii, powstałych przy Katedrze Patrologii KUL zob. R. Wierna, Wykaz prac dyplomowych napisanych w 1945-1995 w KUL z dziedziny antyku chrześcijańskiego, VoxP 13-15(1993-1995) z. 24-29, 557-570.

${ }^{20}$ Por. Patrologia, Lublin-Pelplin 1998, ss. 446.

${ }^{21}$ Owocem wystąpień radiowych są dwa tomy konferencji: Piękno prawdziwe, Pelplin 1998 oraz Pokój serca, Pelplin 1999.

${ }^{22}$ Dotychczas ukazało się pięć tomików materiałów z sympozjów Sekcji Patrystyczej: Wczesnochrześcijańska asceza. Zagadnienia wybrane, red. F. Drączkowski - J. Pałucki, Lublin 1993; Ewangelizacja w epoce patrystycznej. Zagadnienia wybrane, red. F. Drączkowski - J. Pałucki, Lublin 1994; Godność chrześcijanina w nauczaniu Ojców Kościoła, red. F. Drączkowski J. Pałucki, Lublin 1996; Droga doskonalenia chrześcijańskiego. Zagadnienia wybrane, red. 
Katedra Patrologii bardzo aktywnie współpracuje z ośrodkami patrystycznymi za granicą. Od czasu objęcia stanowiska Kierownika Katedry przez ks. F. Drączkowskiego, utrzymuje ona regularne kontakty naukowe z Institutum Altioris Latinitatis w Universita Salesiana w Rzymie, szczególnie z ks. prof. Enrico dal Covolo, który brał udział w sympozjach współorganizowanych przez Katedrę $^{23}$. Pracownicy Katedry Patrologii wielokrotnie wyjeżdżali na różnego rodzaju zagraniczne stypendia naukowe. Ks. prof. F. Drączkowski przebywał w Centro per Le Scienze Religiose w Trydencie (w 1999 r.). Ks. prof. J. Pałucki prowadził wykłady w Instytucie Paulińskim w Noli (w 1993 i 1994 r.) oraz wygłosił referat na międzynarodowym Kongresie Ambrozjańskim w Mediolanie w 1997 roku. Ponadto przebywał w Katolickim Uniwersytecie „Sacro Cuore” w Mediolanie (w 1994 r.) i w Instytucie Patrystycznym „Augustinianum” w Rzymie (w 1995 i 1996 r.). Od 1997 roku systematycznie prowadzi wykłady z patrologii w Instytucie Wyższej Kultury Religijnej we Lwowie. Ks. dr Mariusz Szram był stypendystą Uniwersytetu „La Sorbonne” i Instytutu Katolickiego w Paryżu (w 1996 r.), Uniwersytetu Salezjańskiego i Instytutu Patrystycznego „Augustinianum” w Rzymie (w 1998 r.) oraz Uniwersytetu Katolickiego „Sacro Cuore” w Mediolanie (w 1999 r.). Uczestniczył w międzynarodowym sympozjum „Orygenes a Biblia” w Chantilly we Francji w 1993 roku.

\section{SEMINARIUM PATRYSTYCZNE PRZY KATEDRZE PATROLOGII}

1. Profil organizacyjny. Od roku akademickiego 1982/1983 za zgodą Rady Wydziału Teologii KUL powstało przy Katedrze Patrologii proseminarium naukowe, którym kierował ks. dr hab. Franciszek Drączkowski. Posiedzenia odbywały się raz w tygodniu do końca roku akademickiego 1982/83. W następnym roku akademickim nastąpiła zmiana statusu proseminarium, które zostało podniesione do rangi Seminarium, w związku z zatwierdzeniem przez Ministerstwo Oświaty i Szkolnictwa Wyższego habilitacji ks. Franciszka Drączkowskiego oraz jego zatrudnieniem na Wydziale Teologicznym KUL. W ten sposób, po 12 latach przerwy, przy Katedrze Patrologii zaczęło funkcjonować naukowe seminarium patrystyczne.

Posiedzenia seminarium patrystycznego odbywały się według ustalonego porządku. Posiedzenie otwierała wspólna modlitwa wszystkich zebranych. Na-

F. Drączkowski - J. Pałucki - M. Szram, Lublin 1997; Ojcowie Kościoła wobec filozofii $i$ kultury klasycznej, red. F. Drączkowski - J. Pałucki - M. Szram, Lublin 1998.

${ }^{23}$ Wygłosił referaty m.in. podczas dorocznego spotkania Sekcji Patrystycznej, które miało miejsce w Toruniu w dniach 23-24 IX $1996 \mathrm{r}$. oraz podczas dwudniowego międzynarodowego sympozjum naukowego, zorganizowanego w dniach 24-25 XI 1997 r. przez Katedry Patrologii KUL i Międzywydziałowy Zakład Badań nad Antykiem Chrześcijańskim z okazji 1600 rocznicy śmierci św. Ambrożego. 
stępnie odczytywany był protokół sprawozdawczy z poprzedniego posiedzenia. Uczestnicy wypowiadali się za jego przyjęciem, wnosili swoje uwagi lub nawet poprawki. W dalszej kolejności była sprawdzana lista obecności. Potem następowały ogłoszenia i komunikaty dotyczące: imprez (zjazdy, sympozja, spotkania) związanych z problematyką patrystyczną oraz nowych pozycji wydawniczych, które ukazały się na rynku księgarskim. Punktem centralnym była analiza wybranych tekstów patrystycznych. Następnie uczestnicy przedstawiali wyniki przeprowadzonych przez siebie analiz. Dyskutowane były plany robocze przyszłych prac. Studenci ostatniego roku czytali paragrafy lub całe rozdziały napisanych przez siebie prac, nad którymi potem dyskutowano. Pod koniec prowadzący wyznaczał poszczególnym uczestnikom materiały do opracowania na najbliższy okres. Posiedzenie kończyło się wspólną modlitwą.

Zachowały się protokóły prawie wszystkich posiedzeń seminarium patrystycznego, które odbyły się w latach 1982-1999. Materiały te zawierają się w trzech stukartkowych zeszytach formatu A4. Liczba uczestników biorących udział w posiedzeniach seminarium patrystycznego w okresie od 1983 do 1999 roku kształtowała się różnie. Od początku, tj. od 1983 do roku akademickiego 1990/1991 można mówić o ciągłej tendencji wzrostowej. W roku 1991 wprowadzone zostały „egzaminy wstępne”, z języka łacińskiego i greckiego dla kandydatów pragnących zapisać się na seminarium patrystyczne, co z jednej strony wpłynęło na zmniejszenie się liczby uczestników, a z drugiej strony ułatwiło znacznie pracę.

W omawianym okresie większość uczestników rekrutowała się z grupy alumnów Wyższego Seminarium Duchownego w Lublinie, czyli z kursu „A”. W roku 1986/1987 na seminarium patrystycznym pojawili się pierwsi doktoranci: ks. mgr Józef Grzywaczewski, ks. mgr Jerzy Pałucki oraz o. mgr Alojzy Wiesiołek. W roku następnym do grupy doktorantów dołączyli: ks. Aleksy Kowalski, ks. Piotr Paciorek, ks. Leopold Rzodkiewicz oraz ks. Norbert Widok.

2. Profil naukowy. Problematyka prac magisterskich i doktorskich pisanych na seminarium przy Katedrze Patrologii KUL była związana z indywidualnymi badaniami pracowników Katedry. Przy doborze tematów prac studentów kierowano się przede wszystkim zaleceniami zawartymi w dokumentach Soboru Watykańskiego II. Zwrócono uwagę zwłaszcza na problematykę związaną $\mathrm{z}$ rozwojem duchowym człowieka i jego uświęceniem. Bezpośrednią niejako zachętą do podjęcia tego zagadnienia jest nauka zawarta w Konstytucji dogmatycznej o Kościele Lumen gentium, a zwłaszcza rozdział V, zatytułowany „Powszechne powołanie do świętości w Kościele”. Wydaje się potrzebą chwili przedstawienie konkretnych rozwiązań zawartych w literaturze patrystycznej dotyczącej problematyki doskonalenia chrześcijańskiego. Tematyka prowadzonych prac potwierdza jednoznacznie dominację tej linii badawczej. Są to 
prace, które przedstawiają modele doskonałości chrześcijańskiej oraz programy i środki do ich realizacji proponowane przez Ojców Kościoła. Prace te poświęcone są aretologii patrystycznej, programom doskonalenia chrześcijańskiego, walce ze złem, środkom doskonalenia chrześcijańskiego (modlitwa, post, umartwienie). Drugim nurtem badań jest tematyka chrystologiczna. Problemem dominującym w tej dziedzinie jest onomastyka chrystologiczna w dziełach poszczególnych pisarzy wczesnochrześcijańskich. W dalszej kolejności znajdują się tematy związane z problematyką biblijną, eklezjologią, sakramentologią oraz antropologią patrystyczną. Przedmiotem.badań są także problemy wynikające $\mathrm{z}$ uwarunkowań historycznych związanych z epoką prześladowań (męczeństwo, obraz prześladowań, chrześcijanie wobec świata, wartość nauki chrześcijańskiej) oraz z ruchem monastycznym (ideał życia monastycznego, kler zakonny i świecki). Podejmowane są także tematy związane $\mathrm{z}$ osobistymi zainteresowaniami seminarzystów. Do tego kręgu tematycznego należą: piękno i prawda, motyw serca, angelologia i ekshortacje pastoralne.

$\mathrm{Na}$ uwagę zasługuje też fakt, że w ramach seminarium patrystycznego powstaje coraz więcej prac interdyscyplinarnych. Na przykład w 1995 røku powstała praca pt. Wartości wychowawcze Reguły św. Augustyna, prowadzona na seminarium patrystycznym a będąca równocześnie przygotowaniem do pracy powstającej w Instytucie Pedagogicznym KUL. Obecnie prowadzone są badania na temat wartości wychowawczych Reguły św. Benedykta, wartości wychowawczych postów u św. Leona Wielkiego oraz obrazu dziecka w pismach Jana Chryzostoma (także przy współpracy z seminariami naukowymi z pedagogiki). Wiele innych prac powstaje przy współpracy z katedrami filologii klasycznej (szczególnie ks. prof. A. Eckmanna), jak i różnymi katedrami Wydziału Teologii (np. z zakresu teologii dogmatycznej na temat recepcji myśli św. Augustyna w pismach Tomasza z Akwinu).

Autorzy prac jako bazę źródłową obierali bądź wszystkie dzieła określonego pisarza, bądź jedno tylko dzieło charakterystyczne, o znacznej objętości (np. Enarrationes in Psalmos św Augustyna), lub też dzieła kilku pisarzy. Bazę źródłową badań stanowiły dzieła Ojców Kościoła i pisarzy wczesnochrześcijańskich. Byli nimi: Augustyn, Ambroży, Cyprian, Cezary z Arles, Cyryl Jerozolimski, Euzebiusz z Cezarei, Grzegorz z Nazjanzu, Grzegorz Wielki, Hieronim, Jan Chryzostom, Jan Kasjan, Klemens Aleksandryjski, Laktancjusz, Leon Wielki, Orygenes, Piotr Chryzolog, Pseudo-Jan Chryzostom, Maksym Wyznawca, Minucjusz Feliks, Teodoret z Cyru, Tertulian oraz Apoftegmaty Ojców Pustyni.

Wśród autorów preferowanych na pierwszym miejscu znalazł się św. Augustyn. W dalszej kolejności występuje Klemens Aleksandryjski i Orygenes. W sumie pisma Augustyna, Klemensa Aleksandryjskiego i Orygenesa stanowiły podstawę źródłową dla ponad 50\% wszystkich powstałych opracowań. Można więc mówić o zdecydowanej dominacji tych trzech pisarzy, stanowią- 
cych centrum zainteresowań badawczych magistrantów i doktorantów seminarium patrystycznego. W dalszej kolejności należy wymienić dwóch Wielkich Doktorów Kościoła Zachodniego - Ambrożego i Leona Wielkiego, następnie Cypriana, Grzegorza z Nazjanzu i Grzegorza Wielkiego, Jana Kasjana, Tertuliana, Maksyma Wyznawcę i Jana Chryzostoma. W ogólnym podsumowaniu można mówić o dominacji zainteresowań pismami łacińskimi, w szczególności dorobkiem czterech Wielkich Doktorów Kościoła Zachodniego: Ambrożego, Augustyna, Leona Wielkiego i Grzegorza Wielkiego. Jeśli chodzi o Ojców greckich najwięcej zainteresowania budzili pisarze wywodzący się ze środowiska aleksandryjskiego.

\section{DER BEITRAG VON DER LEHRSTÜHLE DER PATROLOGIE KUL IN DIE ANNÄHRUNG DER LEHRE VON KIRCHENVÄTERN}

\section{(Zusammenfassung)}

Dieser Artikel bildet einen Versuch der Umstrukturierung von Lehrstühle der Patrologie an der Katholischen Universität Lublin ab. Neben dem geschichtliche Vorgang stellte man die verschiedenen Untersuchungsrichtungen vor, die in der Anlehnung an das Erbe von Kirchenvätern, genauso vom Westen wie auch vom Osten, durchführt wurde. Außerdem wird die gesamte Arbeit des patristischenseminars, das am Lehrstuhl der Patrologie veranstaltet ist, aus den verschiedenen Ansichten, genauso die wissenschaftliche, als auch die organisatorische, ausgearbeitet. 